\title{
ORTHODONTIC RETREATMENT OF A MISALIGNED UPPER ARCH MIDLINE CAUSED BY INADEQUATE TREATMENT PLAN
}

\author{
Felix Thungady \\ Lecturer, Orthodontic Department, Faculty of Dentistry, University of Mahasaraswati, Denpasar \\ E-mail: felix.t.drg@gmail.com
}

\begin{abstract}
ABSTRAK
Perawatan ortodonti dimulai dari proses diagnosis dan perencanaan perawatan, menggunakan pendekatan yang berorientasi pada masalah pasien. Salah satu faktor yang dijadikan pertimbangan dalam perawatan ortodonti adalah keseimbangan dan harmoni antara median gigi dan wajah. Faktor estetik ini merupakan salah satu faktor utama pasien hendak melakukan perawatan, bahkan tidak jarang pasien melakukan perawatan ulang dikarenakan tidak puas terhadap hasil perawatan sebelumnya. Seorang wanita berusia 17 tahun, suku Batak, dengan profil cembung, wajah simetris, pergeseran midline rahang atas ke kanan, dan rahang bawah yang retrognatik. Perawatan dimulai dengan pencabutan 24, 34, 44; dilanjutkan leveling dan aligning. Penutupan diastema hasil pencabutan menggunakan kawat stainless steel dengan metode sliding mechanics, dan diselesaikan menggunakan kawat stainless steel 0.017 "x0.025". Perawatan ulang umumnya dilakukan pada pasien yang belum puas terhadap hasil perawatan sebelumnya, hal ini umumnya terjadi akibat proses diagnosis dan perencanaan perawatan yang kurang adekuat. Keberhasilan perawatan ulang ortodontik dimulai dari proses diagnosis dan perencanaan perawatan yang adekuat, disertai pengetahuan, keahlian dan pengalaman.
\end{abstract}

Kata Kunci: orthodontic, retreatment, midline shift.

\section{INTRODUCTION}

Orthodontics has been defined by Salzmann (1943) as 'a branch of science and art of dentistry which deals with the developmental and positional anomalies of the teeth and the jaws as they affect oral health and the physical, esthetic and mental well being of the person.' This definition may be over fifty years old yet even at that time the potential of orthodontics was not lost. The emphasis is on maintenance of oral, physical and mental health of the patient and also his/her esthetics. ${ }^{1}$

One of the goals of orthodontic treatment is to achieve maxillary and mandibular midlines that are coincident, both with each other and with the facial midline. Coincident midlines serve both a functional and an esthetic purpose. ${ }^{2}$ Symmetrical dental arrangement is thought to be a fundamental component of an attractive smile, so that facial and dental midline coordination are basic to appreciation of facial harmony and balance. Although subtle dental to facial midline asymmetry within normal limits is acceptable, significant midline discrepancies can be quite detrimental to dentofacial esthetics. ${ }^{3}$

The process of orthodontic diagnosis and treatment planning lends itself well to the problemoriented approach. Diagnosis in orthodontics, as in other disciplines of dentistry and medicine, requires the collection of an adequate database of information about the patient and the distillation from that database of a comprehensive but clearly stated list of the patient's problems. It is important to recognize that both the patient's perceptions and the doctor's observations are needed in formulating the problem list. Then the task of treatment planning is to synthesize the possible solutions to these specific problems (often there are many possibilities) into a specific treatment strategy that would provide maximum benefit for this particular patient. ${ }^{4}$
Esthetics in dentistry has increasingly become a major concern for patients and often serves as a primary reason for seeking dental care. Dental esthetics can affect not only facial but also social attractiveness. ${ }^{2}$ It is not uncommon for a patient to do an orthodontic retreatment because of an unsatisfactory treatment result caused by inadequate previous treatment plan.

\section{CASE}

A 17 years old Batak female patient, showed a convex facial profile, a symmetric face, an upper arch midline shift to the right and a retrognathic mandible (figure 1).
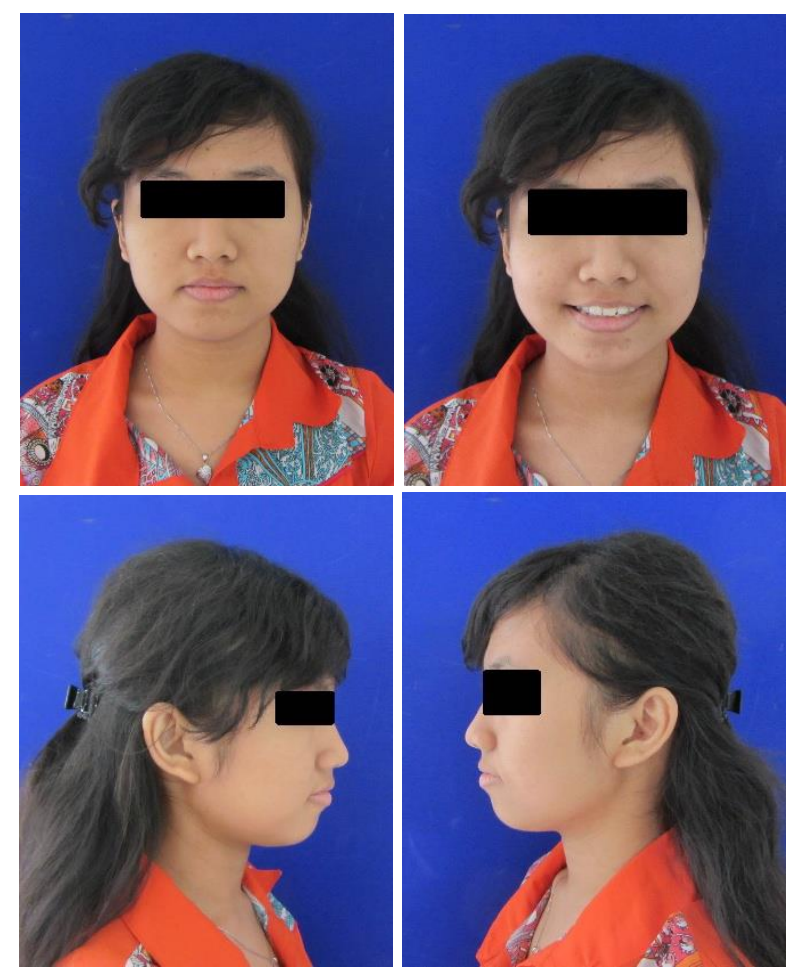
Figure 1. Facial profile before treatment.

Intra oral examination showed a normal mucosal tissue, normal shaped tongue, a parabolic shaped maxilla and mandibular arch, class I molar relation, no canine relation on the right side, class I canine relation on the left side, proclined upper and lower incisor, missing upper right canine (horizontally impacted from panoramic radiograph), lower arch crowding, and a $2.5 \mathrm{~mm}$ upper arch midline shift to the right (figure 2).

Cephalometric analysis showed a convex profile $\left(\angle \mathrm{FH}-\mathrm{Npog} 81^{\circ}, \angle \mathrm{NAPog} 13.5^{\circ}\right.$ ) with maxilla and mandible relate at skeletal class II relation $\left(\angle \mathrm{SNA} 84^{\circ}\right.$, $\angle \mathrm{SNB} 78.5^{\circ}, \angle \mathrm{ANB} 5.5^{\circ}$, wits appraisal AO-BO $\left.3 \mathrm{~mm}\right)$. Proclined upper and lower incisors $\left(\angle \mathrm{I}-\mathrm{NA} 30^{\circ}, \angle \mathrm{I}-\mathrm{NB}\right.$ $41^{\circ}$ ). Nasiolabial angle at $98^{\circ}$, FMA at $30^{\circ}$, FMIA at $40^{\circ}$, and IMPA at $110^{\circ}$.

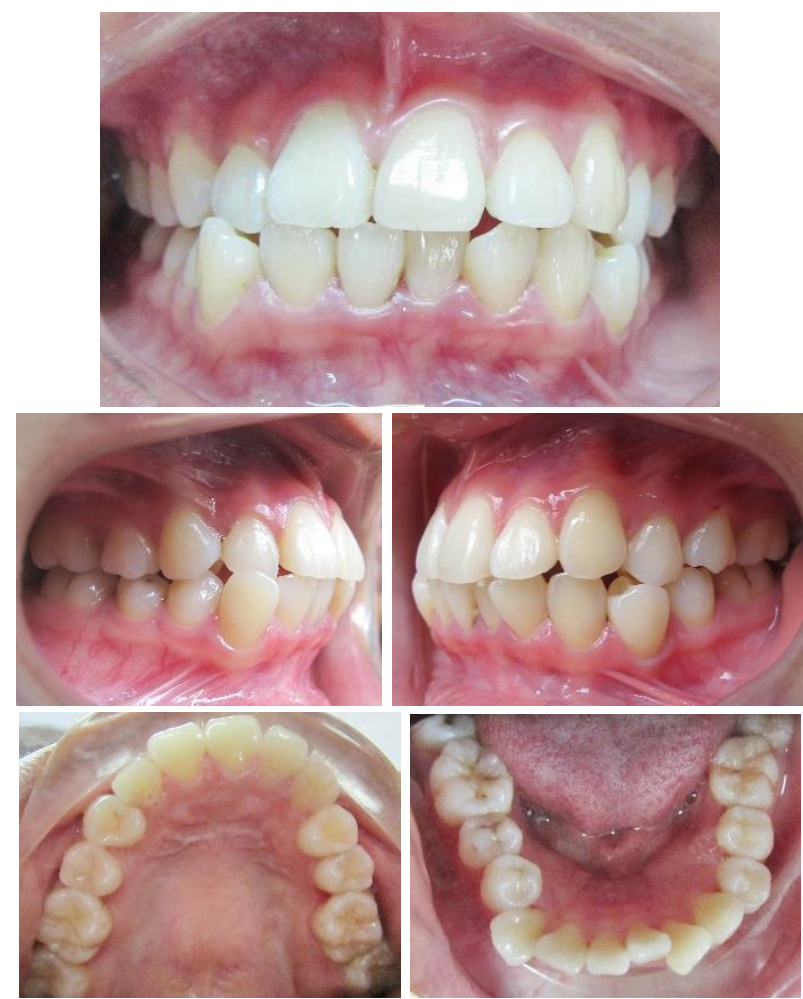

Figure 2. Intra oral photo before treatment.

The patient was diagnosed with a dental class I angle malocclusion, skeletal class II, accompanied by protrusion, lower arch crowding, and a $2.5 \mathrm{~mm}$ upper arch midline shift to the right.

\section{CASE TREATMENT}

Treatment begin with three bicuspids extraction, 24, 34, and 44; then molar bands fitted with buccal tube was placed on 16, 26, 36 and 46; slot 0.018 " straight wire appliance on upper and lower arch. Leveling and aligning started with round 0.012" Nickel-Titanium (NiTi) wire, continued with round 0.014 ", round 0.016 ", and rectangular $0.016 " \mathrm{x} 0.016 " \mathrm{NiTi}$ wire.

Treatment was continued with upper and lower anterior retraction using rectangular 0.016 " $x 0.016$ " Stainless Steel (SS) wire with sliding mechanics. The next phase of treatment begin with arch coordination using 0.016 " 0.022 " SS wire followed by finishing and detailing using a manually bended 0.017 ” 0.025 " SS archwire for minor details.

At the end of treatment, a class I molar relation was maintained, a class I canine relation was maintained on the left side and a "pseudo" class I canine on the right side was achieved using 14 as a "substitute" for 13; protrusion, crowding, midline shift were corrected; better occlusion, and better facial profile were achieved (figure 3, figure 4).

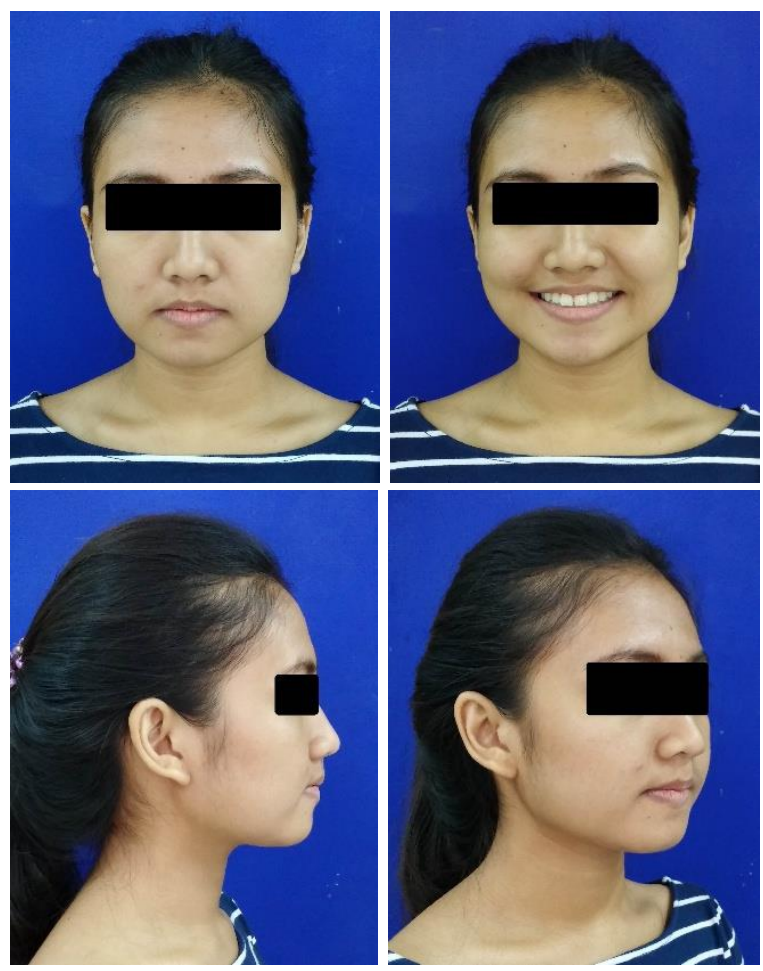

Figure 3. Facial profile after treatment.
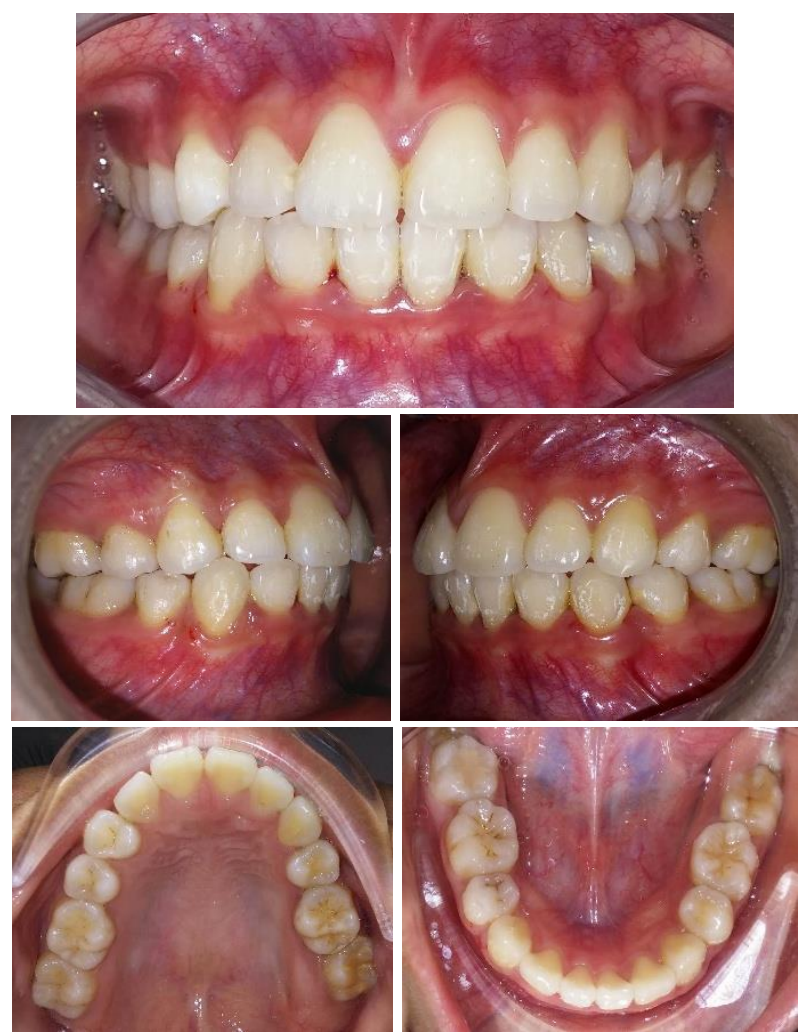

Figure 4. Intra oral photo after treatment. 
Table 1. Cephalometric analysis before and after orthodontic treatment

\begin{tabular}{|c|c|c|}
\hline Variable & $\begin{array}{c}\text { Before } \\
\text { treatment }\end{array}$ & After treatment \\
\hline$\angle$ FH - NPog & $81^{\circ}$ & $82^{\circ}$ \\
\hline$\angle$ NAPog & $13.5^{0}$ & $11.5^{\circ}$ \\
\hline$\angle$ SNA & $84^{\circ}$ & $84^{\circ}$ \\
\hline$\angle \mathrm{SNB}$ & $78.5^{\circ}$ & $80^{\circ}$ \\
\hline$\angle \mathrm{ANB}$ & $5.5^{\circ}$ & $4^{0}$ \\
\hline $\begin{array}{l}\text { Wits Appraisal AO- } \\
\text { BO }\end{array}$ & $3 \mathrm{~mm}$ & $2 \mathrm{~mm}$ \\
\hline$\angle \mathbf{I}-\mathbf{N A}$ & $30^{\circ}$ & $29^{\circ}$ \\
\hline$\angle \mathbf{I}-\mathbf{N B}$ & $41^{0}$ & $34^{\circ}$ \\
\hline Nasolabial angle & $98^{\circ}$ & $106^{0}$ \\
\hline FMA & $30^{\circ}$ & $29^{\circ}$ \\
\hline FMIA & $40^{\circ}$ & $49^{\circ}$ \\
\hline IMPA & $110^{\circ}$ & $102^{\circ}$ \\
\hline
\end{tabular}

\section{DISCUSSIONS}

Correcting the midline shift is not a simple task, especially on a retreatment case. Shyagali et al. found that dental to facial midline discrepancies of $2 \mathrm{~mm}$ or more are likely to be noticed by both orthodontists and non-dental university students. ${ }^{5}$ This is why carefully planned treatment objectives and orthodontic biomechanics accompanied by skill, knowledge and experience are needed to achieve acceptable results.

An inadequate treatment plan may cause many problems, as is evident in this case, where the patient still seeking for a second and even a third opinions because the patient sees no difference even after previous orthodontic treatment was done.

One of the frequently resorted methods to gaining space for orthodontic purposes is by extraction of one or more teeth. Extraction that is undertaken as a part of orthodontic treatment is called therapeutic extraction. ${ }^{6}$ The extraction of three bicuspids was done to get a better space distribution as well as to correct the midline shift; it is also needed to correctly align the teeth and to achieve a better interdigitation.
The decision to leave the impacted upper right canine are made after considering the difficulty and the risk in surgically accessing the canine to properly reposition the canine into the arch. The patient also prefer a non surgical approach to the treatment.

There is only a $1^{0}$ decrease on FMA angle, but is it quite noticeable on the more prominent chin after the treatment.

\section{CONCLUSION AND SUGGESTIONS}

In general, a better occlusion, midline, smile, and more esthetically pleasing facial profile can be achieved in an orthodontic retreatment case by carefully planning treatment objectives and biomechanics.

\section{ACKNOWLEDGEMENT}

The authors thank the Almighty God, the family and the people who helped in the completion of this article

\section{REFERENCES}

1. Singh G. Textbook of Orthodontics, $2^{\text {nd }}$ ed. In: Singh G. Introduction to Orthodontics. New Delhi: Jaypee; 2007. p. 3-6.

2. Thomas JL, Hayes C, Zawaideh S. The Effect of Axial Midline Angulation on Dental Esthetics. Angle Orthod 2003; 73: 359-364.

3. Janson G, Branco NC, Fernandes TMF, Renata Sathler, Garib D, Lauris JRP. Influence of orthodontic treatment, midline position, buccal corridor and smile arc on smile attractiveness. Angle Orthod 2011; 81: 153-161.

4. Proffit WR. Contemporary Orthodontics, $4^{\text {th }}$ ed. St Louis: Mosby Co; 2007. p. 163-233.

5. Shyagali TR, Chandralekha B, Bhayya DP, Kumar S, Balasubramanyam G. Are ratings of dentofacial attractiveness influenced by dentofacial midline discrepancies? Aust Orthod J 2008; 24: 91-95.

6. Bhalajhi SI. Orthodontics The Art and Science, $3^{\text {rd }}$ ed. New Delhi: Arya (Medi) Publishing House; 2004. p. 239-246. 